\title{
Dr. Lee Goodglick: A Valuable Collaborator and A Dear Friend
}

\author{
Eleftherios P. Diamandis \\ Division Head of Clinical Biochemistry; Department of Laboratory Medicine and Pathobiology; University of Toronto \\ and Biochemist-in-Chief at University Health Network and Division Head of Clinical Biochemistry, Mount Sinai \\ Hospital; 600 University Avenue, Toronto, Ontario, Canada M5G 1X5; ediamandis@mtsinai.on.ca
}

I met Dr. Lee Goodglick about 10 years ago at one of the Early Detection Research Network (EDRN) scientific conferences. We were both principal investigators supported by EDRN and both had keen interest in developing novel cancer biomarkers. There were over 200 participants in this conference, but the mutual attraction between the two of us was natural and spontaneous. Lee noticed my presence through my intense questioning of the presenters and my passion to stimulate discussions, sometimes leading to controversy. Lee was the exact opposite; a calm, gentle, low-key individual who would think more and speak less. In this sense, the saying "opposites attract" seemed to fit well to the situation.

During my discussions with Lee, he told me that his then fiancée and later wife, Rietta, was a Canadian and that her mother was living in Toronto. I asked if he is visiting Toronto, and he said yes. So, it wasn't too long before he visited my lab and gave a seminar. Shortly after that, we decided to collaborate on discovering biomarkers for lung carcinoma. This fruitful and enjoyable collaboration produced three scientific publications. ${ }^{1-3}$

We continued our collaboration and friendship for a few years and were seeing each other at least twice a year, at the EDRN scientific workshops. One of the best moments of Lee's life was the adoption of his son, for whom he was very proud. He shared many pictures of his young family. I subsequently noticed that he stopped coming to EDRN conferences and asked Dr. David Chia as to why. He mentioned that Lee was spending more time with his young family and I appreciated that. Unfortunately, as I found later, this was not the main reason for his absence but rather, his sudden diagnosis of cancer, to which he succumbed shortly afterward.

I will always remember Lee and admired his kindness, intelligence, and low-key, anti-pompous approach to everything. Lee was a man with manners and a very accomplished scientist; an overall wonderful human being.

\section{REFERENCES}

1. Diamandis EP, Goodglick L, Planque C, Thornquist MD. Pentraxin-3 is a novel biomarker of lung carcinoma. Clin Cancer Res. 2011;17:2395-9.

2. Planque C, Kulasingam V, Smith CR, Reckamp K, Goodglick L, Diamandis EP. Identification of five candidate lung cancer biomarkers by proteomics analysis of conditioned media of four lung cancer cell lines. Mol Cell Proteomics. 2009;8:2746-58.

3. Planque C, Li L, Zheng Y, Soosaipillai A, Reckamp K, Chia D, Diamandis EP, Goodglick L. A multiparametric serum kallikrein panel for diagnosis of non-small cell lung carcinoma. Clin Cancer Res. 2008;14:1355-62. 
